\title{
Relationship between Human Capacity Building and Performance of Micro and Small Enterprises (Mses) In Kisumu City
}

\author{
Dr. Peter Paul Kithae \\ Director, Open and Distance Learning \\ Management University of Africa, Nairobi, Kenya \\ Dinah C. Keino \\ Director, Quality Assurance \\ Management University of Africa, Nairobi, Keny \\ Phd candidate, JKUAT, and Chepkorir Mbatha Anne
}

\begin{abstract}
This paper focused on the relationship between human capacity building and performance of micro and small enterprises (mses) in kisumu city. Despite the central role of mses in employment, industrial transformation and poverty reduction, the competitiveness and growth prospects of Mses Fall below the levels required to meet challenges of increasing and changing basis for competition. Effective management of a company's human resources is key to business survival in today's world. Human capacity building can be particularly important for small firms. The need for human capacity building for SMEs in Kenya is of great significance if we are to increase the performance and growth of SMEs and at the same time reduce inefficiency, low productivity and the rate of failures of small firm. A descriptive research design was used to carry out the study. A sample of 320 mses was selected for study using quota and convenience sampling technique. Convenience sampling technique is used to simplify data collection procedures and to avoid the complications of simple random method since the researcher just picks on those who happen to be available and are willing, until the desired size is attained. Both qualitative and quantitative research designs which were descriptive in nature were used; as Gall and Borg noted, "Descriptive studies by nature emphasis interpretation." The target population of $\mathbf{3 2 0}$ mses was drawn from the $\mathbf{7 0 1 2}$ businesses that are licensed by the Municipal Council of Kisumu. The study revealed that appropriate business training was considered a very important contributing factor to growth and Lack of business management training facilities was perceived as a major barrier to growth. One of the reasons for this could be the fact that majority of respondents had not been formally trained in the skills needed to operate an enterprise professionally. The study recommended that if training is to be offered to MSEs, it should encourage as little time away from the workplace as possible and that it should be very flexible and inexpensive.
\end{abstract}

Key words: micro and small enterprises, entrepreneurship, Human capacity building, Kisumu city

Institution: The Management University of Africa 


\section{INTRODUCTION AND RESEARCH OBJECTIVES}

The importance and contributions made by micro and small enterprises (MSEs) in world economies has attracted widespread attention from researchers from the time small business research gained significant momentum in the early 1970's (Rutherfoord and Weller, 2002). Work undertaken by Birch (1979) and Storey (1994), which gathered together the evidence from a wide range of studies, has provided policy makers and commentators with evidence of the contributions that small firms make, the difficulties they experience and various attempts and reasoning for government intervention in the sector.

According to Beaver (2002), MSEs have an important role to play in a country's economy, and globally they contribute eighty per cent to a country's economic growth. For instance, "of the 3.7 million businesses in the UK, 99.2 per cent are defined as small businesses, employing fifty seven per cent of the workforce" (Denby, 2001). For many countries in Africa, MSEs and the informal sector represent over $90 \%$ of business and account for $60 \%$ of employment (International Institute for Environment and Development (IIED), 2005). For African countries to achieve long-term, sustainable growth, it is critical that they encourage and enable small and medium-sized entrepreneurs to launch and expand businesses, and enter the formal economy, thus helping MSEs to serve as an engine of growth.

In Kenya, "Micro-enterprises" are those with 9 or fewer workers, "small enterprises" have from 10 to 49 workers, and" medium enterprises" have from 51 to 99 workers (Kithae et al, 2013) . Censuses indicate that micro-enterprises comprise the lion's share of enterprises in Kenya while there are a few small enterprises (Parker and Torres, 1994). According to Kithae et al (2012), medium enterprises are almost non-existent, a concept referred to as the missing middle concept. As well, micro-enterprises are indigenous while the medium-scale and larger manufacturing enterprises are dominated by Asian (Indian) capital.

\section{Statement of the Problem}

Effective management of a company's human resources is key to business survival in today's world. Human capacity building can be particularly important for small firms (Marlow and Patton, 1993) since they tend to be so dependent on human capital. The need for human capacity building for MSEs in Kenya is of great significance if we are to increase the performance and growth of MSE's and at the same time reduce inefficiency, low productivity (Mathis and Jackson, 1991) and the rate of failures of small firms (McEvoy, 1984).

In Kenya MSEs employ about 7.5 million people, or 80 percent of the country's total employment outside the small-scale agriculture. Enterprises in the MSE sector are therefore crucial and important players in national development (Kibas, 2004; King, 1991). The challenges they face which affect their growth and profitability and diminish their ability to contribute effectively to sustainable development need to be determined and addressed (ILO, 2003; Keats and Bracker, 1988). Unless this is done, success will continue to elude them and their growth will continue falling, leading to loss of employment (Kibas, 2004).

MSEs have been recognized as the engine of economic growth and have been put in the development agenda and strategy of many developing African countries. Recognizing the great contributions of MSEs to economic diversification, employment creation, income generation, and poverty alleviation; the government of Kenya has been putting much effort and resources to promote the development of entrepreneurship and MSEs. However, most business support policies and programmes focus on financial assistance for start-up firms and very little has been done to develop entrepreneurial and managerial capability of citizens who start business 
with little or no management skills. It is not only access to finance or the availability of capital that leads to competitiveness: it is how MSEs manage their scarce resources (financial, human and material), market complexities and changes, as well as opportunities and threats in the environment (Temtime, 2002). As argenti (1976) has argued, the most commonly cited cause of business failure is "poor management". As every business operation or activity is directly or indirectly related to management, it is essential to identify and assess the critical managerial factors affecting the performance of MSEs.

With these studies in mind there was need to determine how human capacity building will enhance the performance of MSEs in Kisumu city with a view of identifying the strategies that will mitigate them and improve the growth of the MSEs in the city. MSEs will thus effectively play their role as alternative employment for majority of Kenyans and help reduce unemployment. This study thus focused on the human capacity building for MSEs in Kisumu with an attempt to bridge the existing gap from other studies by seeking answers to the following research questions: (i) What are the current capacity building approaches used by SMEs in Kisumu?; and (ii) How does these human capacity building affect the performance of MSEs in Kisumu?

\section{Objectives of the Study}

The overall objective of the study was to evaluate the impact of human capacity building on performance of Micro and Small Enterprises (MSEs).

The study was guided by the following specific objectives:

I. To establish the current human capacity building approaches used by MSEs in Kisumu city.

II. To establish the impact of human capacity building on the performance of MSEs in Kisumu city

\section{Significant of the Study}

To donor agencies the findings will be of great assistance to donors as they will be able to engage suitable human capacity development agencies (BDS) to help mses improve their marketing capabilities, become innovative to improve quality of their products to survive.

To the government. The findings will give direction on prioritizing the expenditure of the donors and policy makers in consideration to areas where the strategies should be focused so as to effectively promote MSE development

To beneficiaries Information from this study will be useful to both potential and practicing entrepreneurs to realize their weaknesses/shortcomings and rectify them to maximize beneficial effects for their businesses.

\section{Assumptions of the Study}

The study assumed that human capacity building programs have not brought much impact on the performance of the micro and small enterprises and that something need be done to improve its successes. It was further assumed that the respondents to the interview would provide sincere and honest information and views.

\section{Definition of Terms}

This section deals with operational definitions whose role is to indicate the specific manner in which a term or concept is to be applied. Their use may be different in another perspective. This study used the following concepts. 
Micro and small enterprises (MSEs) A micro or small enterprise is an undertaking, which employs between 1 and 20 employees, with capital investment of not more than kshs 30 million. Operational and administrative management lies in the hands of one to three persons who usually make major decisions.

\section{Introduction}

\section{THEORETICAL BACKGROUND AND INFORMING LITERATURE REVIEW}

This chapter reviews literature relevant to the research problem. It is based on several research papers and contributions of various authors, National Development plans, Government sessional papers and other policy documents in the development of entrepreneurs and the micro and small business enterprises. The review gives special consideration to the extent to which human capacity building has succeeded in achieving its goals of enterprise growth.

\section{Human Capacity Building for SMEs}

Human capacity building is the "process of equipping individuals with the understanding, skills, and access to information, knowledge, and training that enables them to perform effectively" (UNDP 1992) in a society. Berg (1993) elaborates on this definition to highlight three main activities: (i) Organization strengthening: the process of institutional development; (ii) Procedural improvements: general functional changes or system reforms; and (iii) Skill enhancement, general education, on the job training (OJT), and professional deepening in crosscutting skills. The success of MSEs in today's turbulent markets depends largely on their ability to engage in environmental scanning activities in order to understand the behavior of and trends in their environment (Temtime, 2001).

The processing of gathering and analysis of interoperating environmental data requires managerial competence and expertise. A previous study (Temtime, 2002) showed that most MSEs do not engage in actual strategic planning as they put too much emphasis on operational bits and pieces. Some prepare business plans just for external validation by banks and creditors rather than coordinating organizational activities. It is not uncommon that ownermanagers often spend too much time fire-fighting rather than leading the firm. As the environment of MSEs is dynamic rather than static, turbulent rather than stable, and requires managerial agility and capability, MSEs should be assisted to think and act strategically. AlMadhoun and Analoui (2003) studied 106 managers in Palestine and found an important relationship between managerial skills and small business development. Enhancing capacity of MSEs has a very great potential to spur economic growth.

\section{Performance and Human Capacity Building for MSEs}

The relationship between HRM activities and performance, in some senses, is problematic. It has been argued that the relationship between HRM and firm performance remains fuzzy and results depend on the population samples and the measures used (Sels et al., 2006). Not withstanding this, there seems a general consensus that best practice HRM activities can enhance business profitability, life span, sales volumes and infrastructural improvement especially where the more sophisticated forms of HRM have been introduced (Way,2002; Hayton, 2003).However, we would also argue that it is important to look at variations within the MSE sector. Each of these variables may differ in their effects on firms of different sizes within the MSE category. As Kieser and Ebers (2006) observe, the size of an organization is a critical influence on its internal structure. Motivating, communicating, provision of training and the development of skills present very different problems for the micro firm of two or three employees as compared with the medium sized firm with perhaps 200 employees. 
Analyses of the links between management training and firm performance in smaller firms have certain methodological weaknesses and the influence of training falls when more "controls" are introduced or when other non-training managerial practices are included. These are shown to have a stronger link to performance than training; no link between training and productivity trends is apparent and, even if a positive correlation were to exist, the methodology is unable to disentangle whether small firms that train perform better or whether small firms that perform better can afford to train. The implication is that prior performance may generate the resources to undertake training, but that it is difficult to assert that training expenditure enhances future performance (Cosh et al., 1998). Further data and analysis are needed to confirm empirically the link between management training and enhanced performance of MSEs.

\section{MSE's in Kenya}

In Kenya, MSEs are defined as businesses in both formal and informal sectors, classified into farm and non-farm categories employing 1-50 workers (Republic of Kenya, 2005). The sector is considered as one of the major contributors to the economy by providing income and employment to a significant proportion of the population (Moyi et al, 2006). Since Independence, the Government has recognized the potential of the MSE sector in employment creation and poverty reduction in its numerous policy documents. The Sessional Paper No. 1 of 1986 on Economic Management for renewed growth was the first to give explicit recognition of the sector's role in economic growth and development. Its recommendations led to the publication of Sessional Paper No. 2 of 1992, Small Enterprises and Jua Kali Development in Kenya that identified the small-scale and Jua Kali enterprise sector for support to assist it to "graduate into the formal sector" and to become a major player in the creation of new jobs and economic growth. This was followed by Sessional Paper No. 2 of 2005 on Development of Micro and Small Enterprises for Wealth and Employment Creation for Poverty Reduction.

The Government of Kenya spelt out its policies towards the small and "Jua Kali" enterprises in two sessional papers and three development plans. In these documents, the government stressed the critical role of small enterprises in the national economy and outlined the policy interventions needed to enhance their growth. The first Sessional paper, Sessional Paper No.1 of 1986 on Economic Management for Renewed Growth, singled out the small enterprise sector and rural economy as future generators of employment (Republic of Kenya, 1992). Three years later, in 1989, the Government prepared a paper, "A Strategy for Small Enterprise Development in Kenya: Toward the Year 2000," in which it documented the major impediments to small enterprise development and enunciated policies for improving the performance of the sector. Critical barriers identified were: difficulty in raising capital; limited managerial skills; regulatory constraints; low marketing skills; limited extension services; and difficulty in getting access to technology.

\section{MSEs in Kisumu City}

The performance and growth of MSEs in Kisumu city is rather low as compared to other MSEs in other towns in Kenya like Kericho and Eldoret (Abuodha and King, 1992). The average lifespan of an MSEs in Kisumu city is six months (GOK, 1999, 2000); the averages of Kericho and Eldoret towns are 16 and 14 months respectively (GOK, 2000), in comparison, this is very low and hence needs to be investigated. The average profits per annum for MSEs in Kisumu have remained at about 2 percent since 2005 (GOK, 2008; Otunga, Opata and Nafukho-Muhia, 2001) while the averages of the profits of MSEs in Kericho and Eldoret grew at 32 percent and 38 percent respectively over the same period (GOK, 2008). The sales volumes of MSEs in Kisumu town grew at 6 percent (GOK, 2008) while the growth rates in the sales volumes of MSEs in Kericho and Eldoret were 24 percent and 28 percent over the same period (GOK, 
2008). The growth rates of MSEs in Kisumu is lower than the national figures of 61 percent and also lower than the rates of its neighboring towns such as Kericho and Eldoret (Kibas, 2004).These are evidence of low growth and development. There is therefore need to understand the correlation of the different human capacity building approaches used by MSEs in Kisumu city with a view of identify the impact it has in improving the performance and growth of the MSEs in the city. Otherwise, the MSEs may not effectively play their role as alternative employment for majority of Kenyans. This will lead to unemployment and retard the overall development of the country.

\section{Impact of Human Capacity Building on the Performance of Mses}

According to Bacon et al. (1996), Human capacity building enhances an employee's productivity and reduces their probability of quitting (as increased wages and other benefits accrue from increased productivity), thus the ease of access to business skills by MSE owners/managers. Booth and Snower (1996) argued that on-the-job training works for most small firms: employees learn in the context in which their skills are used and maintained. However, maintaining competitiveness relies not only on on-the-job or job-specific training, but also on a greater degree of formal training. The advantage of formal training is the gain of accredited experience and knowledge from sources out with their own organization. Surveyed MSEs have called on training providers to offer bite-size training, tailoring courses to the needs of small businesses (Godfrey, 1997). Training providers will need to be more flexible if they wish MSEs to take formal training more seriously. Identifying and clarifying these barriers to skills development in MSEs in more detail is essential if their full productive potential is to be realized.

Existing work rarely considers the factors that determine the level and provision of training. Hannon (1999) in a summary of the literature on training and management development processes in small businesses, refers to management within MSEs as situationally specific, and dependent on a variety of factors such as leadership roles, product or market conditions, business ownership and management structures. While much research in MSE training has focused on claiming a relationship between training and firm performance, far less attention has been directed to understanding the association within the context of the organization, its operating infrastructure and target market. Studies do not explain why some firms are more likely than others to invest in training. Some of the studies establish that organizational characteristics influence the training performance relationship, but they fail to elucidate the contextual factors that influence the decision on training approach. The research studies that claim a mediating effect from sets of variables have not presented statistical interpretations of the significance of these moderating effects.

Whether the problem is in either supply or demand, the Labour Market Survey (2001) showed a clear relationship between business failure and a lack of planning or training by MSEs. Moreover, given that knowledge resources and their renewal are considered to be essential to the growth of firms (Penrose, 1959), it is clearly important to understand the links between training and performance. There are a multitude of other external and internal variables that put weight into the training-performance relationship (Storey, 2004). In this paper we investigate the training-performance link by exploring theoretical gaps in the MSE trainingperformance literature. Matlay and Hyland (1997) and Storey (2004) noted that the contribution of different approaches to training may be particularly relevant given the diversity in the sector, and the fact that smaller firms are considered to prefer informal rather than formal training approaches. 
The general assumption is that those businesses that pay more attention to training and development will be more successful in the long run. This premise underpins a significant investment in MSE training through European Social Funds (Devins and Johnson, 2003) and by national governments in many OECD countries (Storey, 2004). Although this claim is widely established, evidence to show that training and management development enhances MSE performance is equivocal (Storey and Westhead, 1994; Storey, 2004). A large body of the MSE training literature has attempted to address this issue by empirically testing the relationship between training investments - both in terms of resources and time - and firm performance through individual and firm level data. Several recent reviews, however, have shown that the empirical evidence for training influence on firm performance is generally inconsistent and inconclusive (see, for example, Storey, 1994; Morgan et al., 2002; Heraty and Morley, 2003; Storey, 2004).

Studies have shown training to be important in enhancing competitive advantage, facilitating firm growth, and improving profitability (Bartel, 1994; Knoke and Kalleberg, 1994). In addition, training is seen as a useful means of coping with changes fostered by technological innovation, market competition, organizational structuring, and demographic shifts (Knoke and Kalleberg, 1994).

\section{Research Design}

\section{RESEARCH METHODOLOGY}

The study used both qualitative and quantitative research designs which were descriptive in nature; as Gall and Borg (1989) noted, "Descriptive studies by nature emphasis interpretation".

\section{Population}

The target population was drawn from the 7012 businesses that are licensed by the Municipal Council of Kisumu of which 80 percent are MSE's (Kisumu Municipal Office, Sept, 2010). They are distributed in different clusters: which include the Lake Market cluster, the Stage Market, KNA stalls Oile Market Cluster, the Oginga Odinga Road cluster, the Kibuye Market cluster, the Kondele cluster among others (Kisumu Municipal Office, 2010). These MSEs are involved in a variety of business ventures as listed in the Municipality Business Activity Description sheet and include: General traders, wholesalers, retailers, transporters, saloons, fruit vending, computer bureaus, restaurants and many others.

\section{Sampling Design}

The sample consisted of 320 respondents selected from owners and staff of MSEs in Kisumu municipality. The sample size was determined based on the recommendations of Kathuri and Palls (1993), who recommends a sample size of at least 150 for major strata. The study used quota and convenience sampling techniques to select the sample. Convenience sampling technique was used to select the MSEs and the two staff from each MSE. Oso and Onen (2008) define convenience sampling as a technique where a sample is selected from the subjects who happen to be available, on first-come-first-served basis, until the desired number is achieved. Amin (2005) points out that convenience sampling technique is used to simplify data collection procedures and to avoid the complications of simple random method since the researcher just picks on those who happen to be available and are willing, until the desired size is attained. This means that the researcher did not have to trace respondents from their abodes since anybody available can be selected to complete the questionnaires.

\section{Data Collection}

Primary data was collected from the proprietors/managers of the MSEs with the aid of semistructured questionnaires. The researcher administered the questionnaires by drop-and-pick 
method after explaining the purpose of the study and agreeing the time frame for the completion of the questionnaires.

\section{Data Analysis and Presentation}

The Statistical Package for Social Sciences (SPSS) was used as an aid in the analysis. The researcher preferred SPSS because of its ability to cover a wide range of the most common statistical and graphical data analysis.

\section{Introduction}

\section{FINDINGS AND DISCUSSIONS}

This study sought to evaluate the impact of human capacity building on performance of Small and Medium Enterprises in Kisumu city. A combination of both quantitative and qualitative techniques was used in data collection.

The data pertaining to the profile of respondents was analyzed by employing content analysis while descriptive statistics were used in analysis of data pertaining to the second objective of the study. Computation of frequencies and percentages, standard deviations and mean scores were used in data presentation. The information is presented and discussed as per the research objectives of the study.

\section{Response Rate}

Out of the 320 questionnaires that were distributed to the respondents, 307 of them, representing $95.94 \%$ of the questionnaires were returned completed. The high response rate could be attributed to the personal efforts of the researcher, who made a follow up of every questionnaire sent out.

\section{Major Findings}

The findings of this study revealed that there are times when formal training is appropriate for MSEs. Dependent on size, product, market and organizational structures; formal training is both required and/or encouraged by MSE management. It is possible that training is undertaken in these firms as a tactical solution to a problem (Cassell et al., 2002; Hendry et al., 1991) and the demand for training is explicitly related to improving the way the business is operated (Patton and Marlow, 2002). Nevertheless, formal training may still be appropriate to address specific skills or development needs. This will require an understanding of the unique problems that the MSE managers face. Therefore, it is not only the type of training that will be important. Training support for MSEs requires targeted interventions that address specific problems that MSE managers need to resolve, and will require an in-depth understanding of the organization's context and conditions (Perren et al., 1999; Cassell et al., 2002; Patton and Marlow, 2002). Consequently, "when thinking about MSEs, addressing the pertinent human resources issues that emerge from current business priorities should be a key theme" (Cassell et al., 2002), particularly since different styles of learning may be appropriate in different situations and dependent on organizational conditions. While it is increasingly acknowledged that flexible support systems are needed to meet the diverse needs of the small business sector (Small Business Skill Assessment, 2004), the nature of this diversity is not well understood. This study provides information that will allow a more targeted approach to the support of both formal and informal training in the MSE sector, and will therefore be an important contribution to policy development.

This study is a start and provides an important contribution towards an understanding of the complexities involved in developing and sustaining effective small business support that is 
more demand-led rather than supply driven. This is important not least because of the vast amount of money spent by Government on small business support, and the lack of convincing evidence that traditional formal approaches to development advocated by business support agencies provide performance improvements. The empirical analysis and the tentative conceptual framework, provide an important contribution towards a demand-led policy framework in the area of development and training support for MSEs.

\section{CONCLUSIONS}

Sessional Paper No.2 of 1992 on Small Enterprise and "Jua Kali" Development in Kenya, published in 1992 outlined the contributions of the small enterprise sector to the national economy, the key ones being the following: employment creation; enhancing the participation of indigenous Kenyans in the economy; promotion of local savings and investments; promoting the development of entrepreneurship and managerial skills among local Kenyans; and engendering the acquisition of skills among workers. Policies for improving the performance of the sector included measures geared towards the promotion of research, inter-firm linkages, technical training and technology extension. Most respondents in this survey named appropriate business training as very important contributing factors to growth. Lack of business management training facilities was also perceived as a major barrier to growth. One of the reasons for this could be the fact that the majority of respondents had not been formally trained in the skills needed to operate an enterprise professionally. This calls for a need for the design and delivery of specific business and technical training programmes by national and regional institutions responsible for fostering the growth of micro and small enterprises.

\section{Recommendations of the Study}

Based on findings of the study, it is expected that the stakeholders, who include the Government, the MSE owners and the agencies offering various support mechanisms to the MSEs will gain a better understanding of the impact of human capacity building on performance of Micro and Small Enterprises. The following measures are recommended in order to enhance capacity building of MSEs in Kenya:

This study identifies that the research, management, and policy development of training in the MSE sector needs to be more open and flexible in order to address the idiosyncratic nature of MSE requirements.

HRM practices in small firms vary greatly and using static models to define the management training and advice needs of small firms is not tenable.

Research, management and policy instruments of training support will need to interact with, and be responsive to, the subtle distinctions of context that will moderate what is more appropriate, and more likely to be welcomed, in the small business sector.

Factors such as difficulties in accessing training, difficulties in Mses Finding time for their employees to do enough training, rapid changes causing significant adjustments to training needs; cost of training prohibits some firms from engaging in training; and they can rarely afford to invest in formal off-site group training sessions. It is recommended that if training is to be offered to Mses It should encourage as little time away from the workplace; it should be flexible and inexpensive. 


\section{References}

Abuodha, C. and King, K (1992).The Building of an Industrial Society, Change and Development in Kenyan's Informal Sector $(1972$ - 1991). IDS Discussion Paper NO. 292, Nairobi: University of Nairobi, Institute of Development Studies.

Al-Madhoun, M. and Analoui, F. (2003). Managerial skills and SMEs' development in Palestine, Career Development International, Vol. 8 No. 7, pp. 367-79.

Amin, M. (2005). Social science research: Conception, methodology and analysis. Kampala: Makerere University Printers.

Argenti, J. (1976). Corporate Collapse: The Causes and Symptoms, McGraw-Hill, London.

Bacon, N., Ackers, P., Storey, J., and D. Coates (1996). It's a Small World: Managing Human Resources in Small Businesses, International Journal of Human Resource Management, 7, 82-100.

Beaver, G. (2002). Small Business, Entrepreneurship and Enterprise Development, Pearson Education Limited, Harlow, 2002, 28 - 86.

Berg, E. (1993). Rethinking Technical Cooperation: Reforms for Capacity Building in Africa. Washington, D.C.: UNDP/DAI

Betcherman, G., N. Leckie and K. McMullen (1997). “Developing Skills in the Canadian Workplace”, CPRN Study No. W02, Renouf Publishing, Ottawa.

Birch, D. (1979). The Job Generation Process, US Department of Commerce, MIT Program on Neighbourhood and Regional Cange, Cambride, MA.

Booth, A.L. and Snower, D.J. (1996). Acquiring Skills: Market Failures, Their Symptoms and Policy Responses, Centre for Economic Policy Research, London.

Burns, P. (2001), Entrepreneurship and Small Business, Palgrave, Basingstoke.

Cassell, C., Nadin, S., Gray, M. and Clegg, C. (2002). "Exploring human resource management practices in small and medium sized enterprises", Personnel Review, Vol. 31 Nos 5/6, pp. 671-92.

Cosh, A., J. Duncan and A. Hughes (1998). "Investment in Training and Small Firm Growth and Survival: An Empirical Analysis for the UK 1987-95”, Department for Education and Employment, Research Report RR36.

Cushion, N. (1995). "Measuring the success of small management business training", paper presented at 18th ISBA National Conference, University of Paisley, Paisley.

Cushion, N. (1996). "Evaluation of management development in the small business sector", paper presented at ISBA National Small Firms Policy and Research Conference, UCE Business School, Birmingham.

Cushion, Nigel (1995), "How to Succeed in Small Business Training”, City of Norwich College and Nat West Bank.

Devins, D. and Johnson, S. (2003). "Training and development activities in SMEs”, International Small Business Journal, Vol. 21 No. 2, pp. 213-28.

Flanagan D.S. and S.P. Despande (1996). Top management's perceptions of changes in HRM practices after union elections in small firms, Journal of Small Business Management, 34(4), 23-34.

Gibb, A. and Scott, M. (1985). "Strategic awareness, personal commitment and the process of planning in the small business", Journal of Management Studies, Vol. 22 No. 6, pp. 597-632.

GOK. (1985) Kisumu District Development Plan 1994- 1996. Nairobi Ministry of Planning and National Development, Government printers.

GOK. (1986). Sessional paper No. 1 of 1986: Economic Management for renewed Growth. Nairobi Government Printers.

GOK. (1995), National Micro and Small Enterprises in Kenya, collaboration of CBS / ICEG/K-REP, Nairobi.

GOK. (1999), 'National Poverty Eradication Plan, 1999 - 2015' Sessional paper No. 3, Government Printers, Nairobi. 
GOK. (2000), Economic Survey, Government Printers, Nairobi.

Hallier, J. and Butts, S. (1999). “Employers' discovery of training: self-development, employability and the rhetoric of partnership", Employee Relations, Vol. 21 No. 1, pp. 80-95.

Hendry, C., Jones, A., Arthur, M. and Pettigrew, A.M. (1991). "Human resource development in small to mediumsized enterprises", Research Paper No. 88, Department of Employment, Sheffield.

Heraty, N. and Morley, M.J. (2003). "Management development in Ireland: the new organizational wealth?", Journal of Management Development, Vol. 22 No. 1, pp. 60-82.

Hill, R. and Stewart, J. (2000). “Human resource development and small organizations”, Journal of European Industrial Training, Vol. 24 No. 2, pp. 105-17.

Hitt, M.A., Ireland, R.D. and Hoskisson, R.E. (1996). Strategic Management: Competitiveness and Globalization, West Publishing Company, Minneapolis, MN.

Huang, T. (2001). "The relation of training practices and organizational performance in small and medium sized enterprises", Education and Training, Vol. 43 Nos 8/9, pp. 437-44.

Huselid, M.A. (1995). The impact of human resource management practices on turnover, productivity, and corporate financial management, Academy of Management Journal 38(3), 635-672.

ILO (2003) Working out poverty 91st Session. Report of the Director General: ILO

International Institute for Environment and Development (IIED) (2005). "Small and Medium-Sized Enterprises (SMEs) and Corporate Social Responsibility: A Discussion Paper”, June 2005.

Jennings, P.L. and Banfield, P. (1993). "Improving competence in small firms", paper presented at the 16th National Small Firms Policy and Research Conference, The Nottingham Trent University, Nottingham.

Johnston, K. and Loader, K. (2003), "Encouraging SME participation in training: identifying practical approaches”, Journal of European Industrial Training, Vol. 27, pp. 273-80.

Jones, O. (2003). “Competitive advantage in SMEs: towards a conceptual framework”, in Jones, O. and Tilley, F. (Eds), Competitive Advantage in SMEs, Wiley, Chichester, pp. 15-33.

Jones, O. and Macpherson, A. (2006). "Inter-organizational learning and strategic renewal in SMEs: extending the 4i Network”, Long Range Planning, Vol. 39 No. 2, pp. 155-75.

Kathuri, N. K., and Palls, D.A. (1993). Introduction to educational research. Egerton Education Book Series. EMC.

Kessio, J.K (1981), a study of the problems facing small businesses and the effect of management training on the performance of the proprietors: a case study of the Nandi District: Unpublished MBA Research Project, University of Nairobi.

Kibas, P, (2004). Who are Entreprenuers?" Journal of Management (October, 2004), Nairobi: Kenya Institute of Management (PP. 18 - 25).

Kieser, A. and Ebers, M. (2006), Organisations theorien, 6th ed., Kohlhammer. Kiss, K. and Poo'r, J. (2006), "Management and HR characteristics of SMEs in Hungarian regions in the framework of the life-cycle model", Munkau" gyi Szemle, Vol. 50 No. 9, pp. 14-19.

Kitching, J. and Blackburn, R. (2002), the Nature of Training and Motivation to Train in Small Firms, Small Business Research Centre, Kingston University, London.

Kithae P., Awuor, E. Letting N. \& Gesimba P. (2013): Impact of TVET Institutions as Drivers of Innovative Skills for Sustainable Development in Kenya, Kenya Journal of Technical and Vocational Education and Training (KJ-TVET) Vol. 2, Nairobi. Kenya

Kithae P., Gakure, R \& Munyao l. (2012): The place of Micro and Small Enterprises in Achievement of Kenya's vision 2030; journal of US-China public Administration, ISSN 1548-6591 Vol,9 No. 12 pg 1432-1440

Knoke, D., and A. L. Kalleberg (1994). Job training in U.S. organizations, American Sociological Review, 59(4), 537546.

Labour Market Survey (2001). Small and Medium Enterprise (SME) Statistics for the UK, HMSO, London. 
Kithae, P. P., \& Keino, D. C. (2016). Relationship between Huan Capacity Building and Performance of Micro and Small Enterprises (Mses) in Kisumu City. Archives of Business Research, 4(1), 139-151.

Marlow, S., and D. Patton (1993). Managing the employment relationship in the small firm: Possibilities for human resource management, International Small Business Journal, 11(4), 57-64.

Marshall, J., Alderman, N., Wong, C. and Thwaites, A. (1993). “The impact of government assisted management training and development on small and medium-sized enterprises in Britain”, Environment and Planning, Vol. 11, pp. 331-48.

Mathis, R.L. and I. H. Jackson (1991). Personnel/Human Resource Management, West Publishing Company, St. Paul, Minn.

Matlay, H. (1997), "The paradox of training in the small business sector of the British economy”, Journal of Vocational Education and Training, Vol. 49, pp. 573-89.

Matlay, H. (1999). "Vocational education, training and organizational change: a small business perspective", Strategic Change, Vol. 8 No. 5, pp. 277-89.

Morgan, A., Mayes, S. and Smith, E. (2002). "The age of business, its potential to learn and the need for support”, report for the Small Business Service, Trends Business Research, and Newcastle upon Tyne.

Moyi, E., Otieno, G., Mumo, I. and Ronge, E. (2006), Developing a Marketing Model for MSEs in Kenya, KIPPRA, Nairobi, Kenya.

Mugenda A and Mugenda M (2003), Research Methods: Quantative and Qualitative Approaches, ACTS Publishers, Nairobi.

OECD (2000a), “High-Growth SMEs: Phase II Synthesis Report”, DSTI/IND/PME (2000)3.

OECD (2000) Organization for Economic Co-operation and Development (OECD) (2000). "OECD study highlights role of small and medium enterprises in job creation", available at: www1.oecd.org/media/publish/pb00-11a.htm (accessed 8 August 2004).

Oso, W. Y., and Onen, D. (2008). A general guide to writing research proposal and report. A handbook for beginning researchers (2nd Ed.). Kampala; Uganda: Makerere University Printery.

Otunga R, Opata G and Nafukho - Muhia F (2001), "Women Entrepreneurs in Eldoret Town: Their Socio Economic Background and Business Performance,"

Patton, D. and Marlow, S. (2002). "The determinants of management training within smaller firms in the UK. What role does strategy play?” Journal of Small Business and Enterprise Development, Vol. 9 No. 3, pp. 260-70.

Patton, D., Marlow, S. and Hannon, P. (2000). "The relationship between training and small firm performance: research frameworks and lost questions", International Small Business Journal, Vol. 19 No. 1, pp. 11-27.

Penrose, E. (1959). The Theory of the Growth of the Firm, Oxford University Press, Oxford.

Perry, J.L. (1993). Strategic human resource management, Review of Public Personnel Administration, 13(4), 5071.

Pfeffer, J. (1994). Competitive advantage through people: Unleashing the power of the workforce, Harvard Business School Press, Boston.

Prahalad, C.K. (1983). Developing strategic capability: An agenda for top management, Human Resource Management, 22(3), 237-254.

Republic of Kenya (1992). "Sessional Paper No. 2 on Small Enterprises and Jua Kali Development in Kenya." Nairobi: Government Printer, 1992, 85-90.

Republic of Kenya (2005), 'Sessional Paper No. 2 of 2005: Development of Micro and Small Enterprises for Wealth and Employment Creation for Poverty Reduction’ Government Printer, Nairobi.

Rutherfoord and Weller (2002). Small Business Research and Policy: Linking up Small Business Policy Practice with the evidence base, Proceedings of the 32nd EISB Conference, CERAM, Sophia Antipolis, and France.

Small Business Skill Assessment (2004). Sharing Successful Business Practice. Research Report, Small Firms Enterprise Development Initiative, Sheffield.

Storey, D. J. (1994), Understanding the Small Firm Sector, Routledge, London. 
Storey, D.J. (2004), “Exploring the link among small firms, between management training and firm performance: a comparison between the UK and other OECD countries", International Journal of Human Resource Management, Vol. 15 No. 1, pp. 112-30.

Storey, D.J. and Westhead, P. (1997). “Management training in small firms - a case of market failure?”, Human Resource Management Journal, Vol. 7 No. 2, pp. 61-71.

Storey, J. and Westhead, P. (1996), "Management training and small firm performance: why is the link so weak", International Small Business Journal, Vol. 14 No. 4, pp. 13-24.

Temtime, Z.T. (2001). The environmental scanning behavior of small and medium enterprises in developing economies: evidence from Botswana, Pakistan Journal of Applied Sciences, Vol. 1 No. 2, pp. 263-9.

Temtime, Z.T. (2002). The planning behavior of SMEs in developing economies: a 